\title{
HUBUNGAN KADAR EKSKRESI IODIUM URINE (EIU) DENGAN KEJADIAN GONDOK PADA ANAK USIA SEKOLAH DI DAERAH ENDEMIS GAKI
}

\author{
Bibit Nasrokhatun Diniah \\ STIKes Kuningan \\ bibitnasrokhatundiniah@gmail.com
}

\begin{abstract}
Abstrak
Permasalahan yang umumnya terdapat di daerah endemis GAKI adalah kejadian pembesaran kelenjar tiroid (gondok). Gondok merupakan salah satu manifestasi klinis dari kondisi GAKI. Faktor-faktor yang dapat menyebabkan timbulnya gondok tidak hanya keadaan defisiensi iodium saja, akan tetapi keadaan ekses iodium atau kelebihan asupan iodium pada seseorang dapat menyebabkan gondok. Ekses iodium yang terjadi secara terus menerus akan dapat mengganggu proses sintesis hormon tiroid. Penelitian ini bertujuan untuk menganalisis hubungan antara kadar EIU dengan kejadian gondok.

Jenis penelitian adalah observasional analitik dengan desain cross sectional. Sampel merupakan anak usia sekolah (6-12) sebanyak 51 anak dengan teknik penentuan sampel purposive sampling. Pengukuran kadar EIU dengan metode laboratorium Ammonium Persulphate Digestion Method dan pengukuran kejadian gondok menggunakan metode palpasi.

Sebanyak 51 anak (100\%) memiliki kadar EIU diatas batas kecukupan (120 $\mu \mathrm{g} / \mathrm{dL}$ );min $152 \mu \mathrm{g} / \mathrm{dL}$; maks $284 \mu \mathrm{g} / \mathrm{dL}$; mean 251,76 $\mu \mathrm{g} / \mathrm{dL}$, sebanyak 39,2\% responden menderita gondok, meliputi grade 1 sebesar 37,2\% dan grade 2 sebesar $2 \%$. Tidak terdapat hubungan yang signifikan antara Kadar Ekskresi Iodium Urine (EIU) dengan kejadian gondok $(\mathrm{p}=0,743)$.
\end{abstract}

Kata kunci $\quad$ : Kadar Ekskresi Iodium Urine (EIU), Gondok, Anak Sekolah

\section{Pendahuluan}

Proses pertumbuhan dan mikro dan makro. Salah satu mineral mikro perkembangan manusia didukung dengan yang memiliki peran penting adalah kecukupan konsumsi berbagai mineral iodium. Dalam pertumbuhan sistem 
JURNAL ILMU KESEHATAN BHAKTI HUSADA:

HEALTH SCIENCES JOURNAL, Vol. 11 No. 02, DESEMBER 2020 DOI: $10.34305 /$ jikbh.v11i2.168
Ciptaan disebarluaskan di bawah Lisensi Creative Commons AtribusiNonKomersial-BerbagiSerupa 4.0 fisiologis tubuh manusia, iodium berperan dalam pembentukan hormon tiroid. Sehingga kadar hormon tiroid seseorang akan dipengaruhi oleh jumlah konsumsi iodiumnya. Peranan penting iodium dalam tubuh manusia ditunjukkan dengan berbagai macam gangguan kesehatan yang dapat terjadi jika seseorang mengalami kekurangan iodium (GAKI). Gangguan akibat kekurangan iodium dapat menyebabkan berbagai macam manifestasi klinis diantaranya adalah kejadian gondok (Harjatmo et al., 2017).

Indikator suatu daerah memiliki situasi GAKI ditunjukkan dengan hasil pemeriksaan Total Goiter Rate (TGR). Berdasarkan survei evaluasi Rekapitulasi Hasil Palpasi GAKI Pada Anak Sekolah, Dinas Kesehatan Kabupaten Brebes 2014 (2014) TGR Nasional anak sekolah sebesar 11,2\% dengan median kadar EIU sebesar $229 \mu \mathrm{g} / \mathrm{L}$. TGR adalah angka prevalensi goiter yang dihitung berdasarkan stadium pembesaran kelenjar gondok, baik yang teraba (palpable) maupun yang terlihat (visible) (Kartono \& Moeljanto, 2009).

Keadaan di Indonesia GAKI masih menjadi permasalahan gizi yang utama, hal ini dikarenakan masih banyaknya penduduk yaitu 42 juta orang yang tinggal di daerah endemis GAKI; 10 juta orang masih menderita gondok dan sebanyak 750 ribu orang menderita kretin. Kekurangan iodium bisa dialami oleh semua kelompok umur. Pada usia anak-anak dan remaja dapat menyebabkan gondok, hipotiroidisme, gangguan fungsi mental, rendahnya prestasi belajar, dan pertumbuhan terhambat. Gondok disebabkan karena defisiensi iodium dalam makanan yang dapat menyebabkan terjadinya kasus gondok endemik. Kasus gondok endemik umum terjadi di daerah dengan diet garam yodium kurang (Susanto, 2009).

Gondok merupakan manifestasi klinis dari kondisi GAKI, sehingga keberadaan kasus gondok di masyarakat dapat dijadikan ukuran untuk menggambarkan permasalahan dampak lain dari kondisi GAKI seperti kretinisme, gangguan psikomotor, gangguan perilaku termasuk risiko iodine induced hyperthyroidism (IIH). Oleh karena itu gondok pada anak-anak lebih berisiko dibanding pada orang dewasa, sebab anakanak masih dalam masa pertumbuhan dan perkembangan (Sebotsa et al., 2009; Verma \& Raghuvanshi, 2001)

Kabupaten Brebes merupakan daerah endemis GAKI. Salah satu 
JURNAL ILMU KESEHATAN BHAKTI HUSADA:

HEALTH SCIENCES JOURNAL, Vol. 11 No. 02, DESEMBER 2020 DOI: $10.34305 /$ jikbh.v11i2.168
Ciptaan disebarluaskan di bawah Lisensi Creative Commons Atribusi-

NonKomersial-BerbagiSerupa 4.0 kecamatan dengan TGR tertinggi pada tahun 2014 adalah Kecamatan Bulakamba, dengan angka $50.46 \%$, sehingga masuk dalam kategori daerah endemis berat (>30\%).(Dinkes Brebes 2014).

Permasalahan baru yang saat ini terjadi di daerah endemis GAKI yaitu adanya kasus iodium ekses (kelebihan iodium). Defisiensi atau ekses iodium dapat diketahui dengan melakukan pemeriksaan kadar iodium dalam urine seseorang. Hasil pemeriksaan kadar iodium urine dapat menggambarkan perkiraan asupan iodium yang bersumber dari makanan yang dikonsumsi oleh seseorang. Sebagaimana keadaan kekurangan iodium, ekses iodium juga memiliki risiko yang sama terhadap kesehatan, diantaranya dapat mengakibatkan tiroiditis, hipertiroid,

\section{Metode}

Penelitian ini merupakan jenis penelitian observasional dengan desain cross sectional (potong-lintang). Lokasi penelitian dilakukan di daerah endemis GAKI yaitu Kecamatan Bulakamba Kabupaten Brebes. Populasi dalam penelitian meliputi populasi sasaran dan populasi studi. Populasi sasaran merupakan

Pengukuran kadar ekskresi iodium urine dilakukan dengan Ammonium hipotiroid, dan berbagai dampak iodine induced hyperthyroidism (IIH) serta goiter (gondok). WHO merekomendasikan kebutuhan masukan iodium harian untuk anak sekolah umur 6-12 tahun adalah sebesar $120 \mu \mathrm{g}$ sehari (Bürgi, 2010; Vanderpump, 2011).

Keadaan kelebihan (ekses) iodium di suatu wilayah dapat dijadikan sebagai indikator adanya gangguan dalam asupan iodium masyarakatnya. Sama halnya dengan kondisi defisiensi, ekses iodium juga sangat erat kaitannya dengan prevalensi kejadian gondok terutama di daerah endemis GAKI. Penelitian ini bertujuan untuk mengetahui gambaran dan hubungan antara kadar ekskresi iodium urine pada anak usia sekolah dengan kejadian gondok di daerah endemis GAKI. semua anak usia sekolah 6-12 tahun. Sedangkan populasi studi merupakan anak usia sekolah 6-12 tahun yang hidup atau tinggal di Desa Grinting Kecamatan Bulakamba Kabupaten Brebes. Jumlah sampel sebanyak 51 anak yang dipilih menggunakan teknik simple random sampling.

Persulphate Digestion Method (APDM) dan batas kecukupan asupan yodium pada anak- 
JURNAL ILMU KESEHATAN BHAKTI HUSADA:

HEALTH SCIENCES JOURNAL, Vol. 11 No. 02, DESEMBER 2020

DOI: $10.34305 /$ jikbh.v11i2.168
Ciptaan disebarluaskan di bawah

Lisensi Creative Commons Atribusi-

NonKomersial-BerbagiSerupa 4.0 anak adalah $120 \mu \mathrm{g} / \mathrm{dL}$. Pemeriksaan kelenjar tiroid diukur menggunakan metode palpasi yang dilakukan oleh petugas terlatih dari Puskesmas Kluwut Kec. Bulakamba. Menurut Djokomoeljanto pemeriksaan kelenjar tiroid dengan metode palpasi apabila dilakukan dengan baik dan sesuai standar maka dapat mengidentifikasi kejadian gondok sama baiknya dengan metode ultrasonography (USG). Pada penelitian ini pemeriksaan kelenjar tiroid

\section{Hasil Dan Pembahasan}

\section{Karakteristik Responden}

Karakteristik responden dapat dilakukan untuk mengetahui prevalensi kejadian gondok yang terjadi pada responden dan untuk melihat sampai mana tingkat keparahan kejadian gondok tersebut dengan kategori grade 1 dan 2 berarti gondok dan grade 0 berarti tidak gondok. Grade 0 maksudnya tidak teraba dan tidak terlihat adanya pembesaran kelenjar tiroid, sedangkan grade 1 dan 2 maksudnya teraba atau terlihat adanya pembesaran kelenjar tiroid.

meliputi: umur, jenis kelamin, tinggi badan, berat badan, status gizi (IMT/U) pendidikan orang tua dan pekerjaan orang tua.

dilihat pada tabel 1 di bawah ini yang

Tabel 1 Distribusi Frekuensi Karakteristik Subyek Penelitian pada Siswa SD Negeri 01

Grinting Kecamatan Bulakamba Kabupaten Brebes

\begin{tabular}{lcc}
\hline \multicolumn{1}{c}{ Karakteristik Responden } & $\mathbf{n}$ & \% \\
Umur (tahun) & & \\
- Mean (Simpang baku) & $9,78(0,66)$ \\
- Median (Min-Maks) & $9,80(8,8-11,3)$ & \\
- IK95\% & $9,6-9,9$ & 60,8 \\
Jenis kelamin & & 39,2 \\
- Laki-laki & 31 & \\
- Perempuan & 20 & \\
Tinggi badan (cm) & & \\
- Mean (simpang baku) & $129,70(6,02)$ & \\
- Median (Min-Maks) & $129,1(117,5-145,7)$ & \\
- IK95\% & $(128,01-131,39)$ & \\
Berat badan (kg) & $27,66(8,64)$ & \\
- Mean (simpang baku) & $24,60(17,4-59,3)$ & 2,0 \\
- Median (Min-Maks) & $25,23-30,09$ \\
- IK95\% & 1 & 7,8 \\
Status Gizi ((IMT/U) Indeks Massa Tubuh menurut Umur) & 7,8 \\
- Sangat kurus (<-3SD) & 6 & 7,8 \\
- Kurus (-3SD - <-2SD) & 36 & \\
- Normal (-2SD - 1SD) & 4 & \\
- Gemuk (>1SD - 2SD) & 4 & \\
- Obesitas (>2SD) & & \\
\hline
\end{tabular}




Pendidikan Ayah
- Tidak tamat SD
- Tamat SD
- Tamat SLTP
- Tamat SLTA
- Tamat Akademi
Pendidikan Ibu
- Tidak tamat SD
- Tamat SD
- Tamat SLTP
- Tamat SLTA
- Tamat PT
Pekerjaan Ayah
- Tidak Bekerja
- Buruh Tani
- Petani Pemilik
- Nelayan
- Pedagang/wiraswasta
- Pegawai Swasta
- PNS
- Lain-lain
Pekerjaan Ibu
- Tidak bekerja
- Buruh tani
- Petani pemilik
- Pedagang/wiraswasta
- Pegawai Swasta
- Lain-lain

\begin{tabular}{cc}
10 & 19,6 \\
26 & 51,0 \\
4 & 7,8 \\
10 & 19,6 \\
1 & 2,0 \\
& \\
9 & 17,6 \\
30 & 58,8 \\
6 & 11,8 \\
5 & 9,8 \\
1 & 2,0 \\
& \\
2 & 3,9 \\
13 & 25,5 \\
4 & 7,8 \\
5 & 9,8 \\
10 & 19,6 \\
7 & 13,7 \\
1 & 2,0 \\
9 & 17,6 \\
& \\
14 & 27,5 \\
5 & 9,8 \\
2 & 3,9 \\
13 & 25,5 \\
5 & 9,8 \\
1 & 2,0 \\
11 & 21,6 \\
\hline & \\
& \\
& \\
&
\end{tabular}

status gizi responden dengan menggunakan

Berdasarkan tabel di atas diketahui bahwa umur subyek penelitian berada pada rentang 8 tahun 8 bulan -11 tahun 3 bulan dan nilai mediannya 9 tahun 8 bulan. Sebagian besar responden berjenis kelamin laki-laki yaitu 31 anak (60,8\%), sedangkan responden jenis kelamin perempuan yaitu 20 anak (39,2\%). Pada pengukuran antropometri yang meliputi tinggi badan dan berat badan menunjukan rerata tinggi badan responden 129,70 $\mathrm{cm}$ dan median berat badan responden $24,60 \mathrm{~kg}$. Penentuan
Indeks Massa Tubuh (IMT) menurut umur berdasarkan standar antropometri kementerian kesehatan yang diterapkan pada anak umur 5-18 tahun, menunjukan bahwa status gizi responden sebagian besar normal yaitu sebanyak 36 responden $(70,6 \%)$.

Karakteristik orang tua responden meliputi tingkat pendidikan dan jenis pekerjaan orang tua. Tingkat pendidikan ayah dan ibu sebagian besar tamat SD, yaitu sebanyak 26 orang $(51,0 \%)$ untuk tingkat pendidikan ayah dan sebanyak 30

E-ISSN 2623-1204 P-ISSN 2252-9462 | 156 
JURNAL ILMU KESEHATAN BHAKTI HUSADA:

HEALTH SCIENCES JOURNAL, Vol. 11 No. 02, DESEMBER 2020 DOI: $10.34305 /$ jikbh.v11i2.168
Ciptaan disebarluaskan di bawah Lisensi Creative Commons Atribusi-

NonKomersial-BerbagiSerupa 4.0 orang $(58,8 \%)$ untuk tingkat pendidikan ibu. Tingkat pekerjaan ayah sebagian besar sebagai buruh tani sebanyak 13 orang $(25,5 \%)$,sedangkan pekerjaan ibu sebagian besar tidak bekerja yaitu sebanyak 14 orang $(27,5 \%)$.

\section{Kadar Ekskresi Yodium Urine (EYU)}

Kadar Ekskresi Iodium Urine (EIU) memiliki nilai minimum $152 \mu \mathrm{g} / \mathrm{dL}$ dan nilai maksimum $284 \mu \mathrm{g} / \mathrm{dL}$. Batas kecukupan asupan yodium pada anak-anak adalah $120 \mu \mathrm{g} / \mathrm{dL}$, sehingga dari hasil penelitian ini dapat diperlihatkan bahwa Kadar Ekskresi Iodium Urine (EIU) anakanak semuanya di atas kadar nilai kecukupannya. Untuk memudahkan dalam melakukan analisis data nilai Kadar Ekskresi Iodium Urine (EIU) dikategorikan menggunakan cut off point nilai median karena Kadar EYU berdistribusi tidak normal. Nilai median Kadar EIU sebesar 266,0 $\mu \mathrm{g} / \mathrm{dL}$ dengan distribusi Kadar EIU responden dikatakan berlebih apabila memiliki Kadar EIU $\geq 266,0 \mu \mathrm{g} / \mathrm{dL}$ sebanyak 26 anak (51\%) dan responden dengan Kadar EYU cukup apabila nilainya $<266,0 \mu \mathrm{g} / \mathrm{dL}$ yaitu sebanyak 25 anak $(49 \%)$.

Analisis Deskriptif Kadar Ekskresi Iodium Urine selengkapnya diperlihatkan pada tabel 2 di bawah ini:

Tabel 2 Hasil Analisis Deskriptif Kadar Ekskresi Yodium Urine (EYU)

\begin{tabular}{cc}
\hline Ekskresi Yodium Urine (EYU) & $\mathbf{n}(\mathbf{\%})$ \\
Mean (simpang baku) & $251,76(35,05)$ \\
Median & 266,0 \\
IK95\% & $241,91-261,62$ \\
Min-maks & $\mathbf{1 5 2 - 2 8 4}$ \\
Kategori Ekskresi Yodium Urine (EYU) & $26(51,0)$ \\
Berlebih $(\geq$ median $=266,0 \mu \mathrm{g} / \mathrm{dL})$ & $25(49,0)$ \\
Cukup $\quad(<$ median=266,0 $\mu \mathrm{g} / \mathrm{dL})$ & \\
\hline
\end{tabular}

tabel 3 diketahui bahwa dari 51 responden

\section{Kejadian Gondok}

Prevalensi kejadian gondok dapat diketahui dengan melakukan pemeriksaan kelenjar tiroid subyek penelitian dengan menggunakan metode palpasi. Berdasarkan yang diperiksa, terdapat 20 anak yang menderita gondok $(39,2 \%)$. Sedangkan dari 20 responden yang menderita gondok dapat diketahui tingkat keparahan kejadian gondok meliputi grade 1 (teraba) sebanyak 19 responden $(37,2 \%)$ dan grade 2 (teraba dan terlihat) sebanyak 1 responden $(2 \%)$. 
Analisis Kejadian Goiter pada anak bawah ini:

selengkapnya diperlihatkan pada tabel 3 di

Ciptaan disebarluaskan di bawah Lisensi Creative Commons Atribusi-

Tabel 3 Hasil Analisis Deskriptif Kejadian Gondok pada Anak

\begin{tabular}{cc}
\hline Kejadian Goiter & $\mathbf{n}(\boldsymbol{\%})$ \\
Positif & $20(39,2)$ \\
Negatif & $31(60,8)$ \\
Kategori Kejadian Goiter & $31(60,8)$ \\
Grade 0 & $19(37,2)$ \\
Grade 1 & $1(2,0)$ \\
Grade 2 & \\
\hline
\end{tabular}

Hubungan Kadar Iodium Urine (EIU) dengan Kejadian Gondok

Berdasarkan tabel 4 di bawah ini menunjukkan bahwa dari responden yang memiliki Kadar EIU berlebih yaitu sebanyak 26 responden, terdapat 9 responden $(34,6 \%)$ yang menderita gondok, sementara pada pemeriksaan Kadar EIU cukup yaitu sebanyak 25 responden, terdapat 11 responden $(44,0 \%)$ yang menderita gondok. Hasil uji statistik menunjukkan nilai $\mathrm{p}=0,690 ; \mathrm{RP}=0,79$ dan 95\% CI (0,39-1,57), ini menunjukkan bahwa tidak terdapat hubungan yang signifikan antara Kadar Ekskresi Yodium Urine (EYU) dengan kejadian gondok. Hasil uji beda proporsi Kadar Ekskresi Iodium Urine (EIU) dengan kejadian gondok dapat dilihat pada tabel 4 di bawah ini:

\section{Tabel 4 Hasil Analisis Uji Beda Proporsi antara Kadar EIU dengan Kejadian Gondok}

\begin{tabular}{ccccccc}
\hline $\begin{array}{c}\text { Kadar Ekskresi Yodium } \\
\text { Urine (EYU) }\end{array}$ & \multicolumn{9}{c}{ Kejadian Goiter } \\
& Goiter & Tidak Goiter & p & RP \\
& $\mathrm{n}$ & $\%$ & $\mathrm{n}$ & $\%$ & & \\
Berlebih $(\mathrm{n}=26)$ & 9 & 34,6 & 17 & 65,4 & & $0,79^{\mathrm{a}}$ \\
Cukup $(\mathrm{n}=25)$ & 11 & 44,0 & 14 & 56,0 & $0,690 \mathrm{a}$ & $(0,39-1,57)$ \\
Total & $\mathbf{2 0}$ & & $\mathbf{3 1}$ & & & \\
\hline
\end{tabular}

Keterangan: *) Uji Chi-square (signifikan $\mathrm{p}<0,05$ )

Untuk melihat apakah ada beda rerata antara Kadar Ekskresi Iodium Urine (EIU) pada kelompok dengan gondok dan pada kelompok tanpa gondok maka 
JURNAL ILMU KESEHATAN BHAKTI HUSADA:

HEALTH SCIENCES JOURNAL, Vol. 11 No. 02, DESEMBER 2020

DOI: $10.34305 /$ jikbh.v11i2.168
Ciptaan disebarluaskan di bawah

Lisensi Creative Commons Atribusi-

NonKomersial-BerbagiSerupa 4.0

dilakukan analisis uji beda rerata. Iodium Urine (EIU) pada anak penderita Berdasarkan hasil uji statistik diketahui nilai $\mathrm{p}=0,743$, ini menunjukkan bahwa tidak ada perbedaan rerata antara Kadar Ekskresi gondok dan pada anak tanpa gondok. Untuk lebih rinci dapat dilihat pada tabel 5 di bawah ini:

\section{Tabel 5 Hasil Analisis Uji Beda Rerata antara Kadar EIU dengan Kejadian Gondok}

\begin{tabular}{lcc}
\hline Variabel & $\begin{array}{c}\text { Rerata } \\
\text { Kadar } \\
\text { EIU }\end{array}$ & $\begin{array}{c}\text { Nilai } \\
\text { p }\end{array}$ \\
\hline Posistif gondok $(\mathrm{n}=20)$ & 25,15 & 0,743 \\
Negatif gondok $(\mathrm{n}=31)$ & 26,55 & \\
\hline Keterangan: $*$ ) Uji Mann-Whitney (signifikan $\mathrm{p}<0,05)$
\end{tabular}

Analisis tingginya nilai median EIU pada penelitian ini dapat menjadi indikator keberhasilan program penanggulangan GAKI yang dilakukan oleh pemerintah. GAKI merupakan semua spektrum gangguan kesehatan yang dapat terjadi apabila seseorang mengalami kekurangan iodium. Keadaan semacam ini dapat dicegah dengan memastikan bahwa seseorang mendapatkan asupan iodium yang cukup.

Program penanggulangan GAKI yang dilakukan oleh pemerintah diantaranya meliputi Universal Salt Iodization (USI), pemberian minyak iodium baik secara oral atau suntikan (lipiodol) dan program iodinasi sumber air minum (Nasional, 2004). Selain beberapa hal diatas, nilai median EIU juga dapat memperlihatkan ketercapaian distribusi kapsul minyak beriodium bagi masyarakat yang tepat sasaran, dan koordinasi lintas sektoral terhadap penanggulangan GAKI yang sudah baik.

Tubuh manusia tidak mampu mensintesis iodium, maka kecukupan tubuh manusia terhadap iodium dapat dilihat atau dinilai dari makanan dan minuman yang dikonsumsi. Iodium dibutuhkan dalam jumlah yang sangat sedikit (mikro) dan pemeriksaan kadar iodium dalam makanan saat ini masih sulit dilakukan, sehingga indikator terbaik untuk melihat asupan iodium seseorang adalah dengan melihat Kadar Ekskresi Iodium (EIU) dalam urine, karena sebanyak 90\% iodium yang dikonsumsi manusia akan dibuang melalui urine (Dunn, 2002).

Kadar iodium dalam tubuh dianggap berlebihan apabila jumlahnya telah 
JURNAL ILMU KESEHATAN BHAKTI HUSADA:

HEALTH SCIENCES JOURNAL, Vol. 11 No. 02, DESEMBER 2020

DOI: $10.34305 /$ jikbh.v11i2.168
Ciptaan disebarluaskan di bawah

Lisensi Creative Commons Atribusi-

NonKomersial-BerbagiSerupa 4.0 melebihi batas kebutuhan tubuh untuk proses sintesa hormon tiroid. Keadaan kelebihan iodium (iodide excess) terjadi apabila konsumsi iodium dalam dosis berlebih secara terus menerus dan dapat menyebabkan terjadinya hambatan (inhibisi) dalam proses hormonogenesis, sehingga kemudian dapat menyebabkan pada munculnya kejadian gondok pada seseorang (Sudarsono, 2001).

Gondok merupakan pembesaran yang terjadi pada kelenjar tiroid, dimana dapat terjadi pada beberapa kondisi, diantaranya pada kelenjar tiroid yang memproduksi terlalu banyak hormon tiroid (hyperthyroidism), terlalu sedikit memproduksi hormon tiroid (hypothyroidism), atau dengan jumlah hormon tiroid normal (euthyroidism).
Menurut Garber et al., (2012) gondok terjadi karena adanya kelainan pada kelenjar tiroid sehingga kelenjar tiroid mengalami abnormalitas dalam pertumbuhannya.

Pada penelitian ini diketahui bahwa tidak terdapat hubungan yang signifikan antara Kadar EIU dengan Kejadian Gondok pada anak usia sekolah $(\mathrm{p}=0,690)$. Penelitian ini sejalan dengan penelitian yang dilakukan oleh Yustini Alioes, 2010 diketahui bahwa 80 anak $(61,5 \%)$ menderita penyakit gondok dan tidak didapatkan hubungan yang bermakna antara penyakit gondok dan kadar yodium dalam urin $(\mathrm{p}=$ 0,158). hal ini berarti meskipun TGR termasuk dalam daerah endemis GAKI namun, tidak selalu berhubungan dengan hasil pengukuran kadar EIU.

Tabel 6 Hasil Analisis Uji Beda Proporsi antara Jenis Kelamin Responden dengan Kejadian Gondok

\begin{tabular}{|c|c|c|c|c|c|c|}
\hline \multirow[t]{3}{*}{ Jenis Kelamin } & \multicolumn{6}{|c|}{ Kejadian Goiter } \\
\hline & \multicolumn{2}{|c|}{ Goiter } & \multicolumn{2}{|c|}{ Tidak Goiter } & \multirow[t]{2}{*}{$\mathbf{p}$} & \multirow[t]{2}{*}{ RP $(95 \%$ CI $)$} \\
\hline & $\mathrm{n}$ & $\%$ & $\mathrm{n}$ & $\%$ & & \\
\hline Laki-laki $(\mathrm{n}=31)$ & 8 & 25,8 & 23 & 74,2 & & 0,43 \\
\hline Perempuan $(n=20)$ & 12 & 60,0 & 8 & 40,0 & $\begin{array}{c}0,032 \\
\mathrm{a}\end{array}$ & $(0,21-0,86)$ \\
\hline Total & 20 & & 31 & & & \\
\hline
\end{tabular}

Keterangan: *) Uji Chi-square (signifikan $\mathrm{p}<0,05$ )

Tabel 6 di atas menunjukkan bahwa nilai $\mathrm{p}=0,032 ; \mathrm{RP}=0,43$ dan $95 \% \mathrm{CI}(0,21$ $0,86)$ ini berarti terdapat hubungan antara jenis kelamin dengan kejadian gondok dan jenis kelamin memiliki peluang sebesar 0,43 kali untuk menjadi faktor proteksi 
JURNAL ILMU KESEHATAN BHAKTI HUSADA:

HEALTH SCIENCES JOURNAL, Vol. 11 No. 02, DESEMBER 2020 DOI: $10.34305 /$ jikbh.v11i2.168
Ciptaan disebarluaskan di bawah Lisensi Creative Commons AtribusiNonKomersial-BerbagiSerupa 4.0 terjadinya gondok. Hal ini sejalan dengan pernyataan Syaifuddin (2011) dimana gondok lebih sering terjadi pada wanita dengan faktor risiko empat kali lebih besar dibanding laki-laki. Faktor risiko kejadian gondok pada wanita meningkat lebih besar pada masa pubertas dan kehamilan.

Menurut Kartono (1997) prevalensi gondok pada anak perempuan (25\%) lebih besar dari anak laki-laki adalah (19\%). Ini merupakan satu pertanda bahwa kebutuhan tubuh akan yodium pada anak perempuan lebih banyak daripada anak laki-laki. Tingginya prevalensi gondok pada anak perempuan memberikan gambaran kepada generasi mendatang. Puncak prevalensi gondok pada anak perempuan umumnya dicapai pada usia pubertas yaitu 14-16 tahun. Hal ini menimbulkan kekhawatiran karena resiko melahirkan bayi kretin sangat tinggi pada perempuan yang kekurangan yodium jika dibandingkan perempuan yang memiliki kadar yodium normal.

Hasil penelitian ini juga sejalan dengan penelitian Ah Yusuf et al., (2015) yang memperlihatkan bahwa dari 81 responden yang menderita penyakit gondok (grade I dan 2) 48,1\% berjenis kelamin lakilaki dan $51,9 \%$ berjenis kelamin perempuan. Triyono (2004) juga melaporkan gondok lebih sering terjadi pada anak perempuan dibandingkan lakilaki.

Faktor-faktor yang menyebabkan tidak adanya hubungan antara Kadar EIU dengan Kejadian Gondok dapat dipengaruhi oleh beberapa faktor, diantaranya meliputi:

\section{Sensitivitas Kadar EIU sebagai Indikator Keadaan Fungsi Tiroid}

Kadar EIU tidak dapat menggambarkan keadaan fungsi kelenjar tiroid seseorang, meskipun Kadar EIU merupakan indikator yang baik dalam mengukur asupan iodium. Fungsi kelenjar tiroid secara baik dapat diketahui dengan melakukan pengukuran hormon Thyroid Stimulating Hormone (TSH) dan tiroksin (T4). Tingginya kadar TSH dan T4 yang rendah menunjukkan bahwa fungsi kelenjar tiroid kurang aktif. Sebaliknya apabila kadar TSH rendah dan T4 tinggi maka menunjukkan bahwa fungsi kelenjar tiroid yang terlalu aktif (Djokomoeljanto, 2007).

Sebagai indikator status iodium saat ini, TGR sudah banyak ditinggalkan, dikarenakan TGR tidak secara sensitif dan spesifik memperlihatkan perubahan status iodium seseorang. Menurut Zimmermann (2004) TGR merupakan indikator yang baik 
JURNAL ILMU KESEHATAN BHAKTI HUSADA:

HEALTH SCIENCES JOURNAL, Vol. 11 No. 02, DESEMBER 2020 DOI: $10.34305 /$ jikbh.v11i2.168
Ciptaan disebarluaskan di bawah Lisensi Creative Commons AtribusiNonKomersial-BerbagiSerupa 4.0 dalam penentuan status iodium masyarakat untuk jangka panjang, namun penilaian pengaruh konsumsi asupan iodium secara cepat, akan lebih baik jika tidak menggunakan TGR, karena dapat memberikan hasil yang bertentangan dengan nilai median EIU yang merupakan indikator lebih sensitif dan spesifik pada perubahan status iodium masyarakat. Median EIU dianggap sebagai indikator terbaik untuk menilai status iodium, akan tetapi TGR tetap digunakan untuk periode pengamatan yang panjang. Sebagaimana survei GAKI yang dilakukan secara nasional pada tahun 2003, menunjukkan bahwa berdasarkan nilai median EIU tidak terdapat daerah dalam kategori kekurangan iodium, namun berdasarkan data TGR masih terdapat daerah endemis GAKI (Nasional, 2004). Azizi (2009) menyatakan bahwa TGR yang tinggi tersebut merupakan dampak dari kekurangan iodium beberapa tahun sebelumnya. Sehingga, peningkatan TGR pada tahun 2003 merupakan akibat dari kondisi kekurangan iodium beberapa tahun lalu.

Penyebab tidak adanya hubungan dapat diakibatkan karena prevalensi gondok yang muncul dari penelitian ini merupakan hasil atau dampak dari keadaan defisiensi atau kekurangan iodium pada masa lalu dan TGR merupakan indikator jangka panjang program penanggulangan GAKI, sedangkan keadaan ekses iodium yang ditunjukkan dengan tingginya Kadar EIU merupakan indikator penilaian asupan iodium anak pada saat ini (Azizi, 2009). Secara teori EIU dapat mengukur jumlah asupan iodium seseorang, namun sebagai indikator terbaik dalam melihat keadaan fungsi tiroid seseorang sebaiknya dengan melakukan pengukuran kadar TSH dan T4.

Djokomoeljanto (2007) menyatakan bahwa produksi hormon tiroid sangat dipengaruhi oleh umpan produksi TSH (Thyroid Stimulating Hormone). Efek TSH pada tiroid adalah terjadinya perubahan biokimiawi diantaranya meningkatkan sintesis NIS (Natrium Iodida Symporter), sehingga meningkatkan uptake iodida; pengaruh TSH lainnya pada hormon tiroid adalah pada tahapan deiodinasi T4 menjadi T3, sehingga meningkatkan produksi dan sekresi T3 dari tiroid. T3 adalah hormon aktif, karena itu T4 harus diubah dahulu menjadi T3 untuk bisa berfungsi normal di jaringan (Djokomoeljanto, 2007; Price \& Wilson, 2006). Dalam penelitian ini tidak dilakukan pengukuran kadar TSH maupun T4, sehingga sejauh mana keadaan fungsi 
JURNAL ILMU KESEHATAN BHAKTI HUSADA:

HEALTH SCIENCES JOURNAL, Vol. 11 No. 02, DESEMBER 2020

DOI: $10.34305 /$ jikbh.v11i2.168
Ciptaan disebarluaskan di bawah

Lisensi Creative Commons Atribusi-

NonKomersial-BerbagiSerupa 4.0 tiroid anak belum dapat diketahui dengan

\section{Defisiensi Energi Protein}

Faktor kedua penyebab tidak adanya hubungan dapat dikarenakan oleh faktor defisiensi energi protein pada anak-anak. Berdasarkan tabel 1 pada penelitian ini diperlihatkan bahwa dari 51 anak didapatkan sebanyak 36 anak atau $70,6 \%$ sudah memiliki status gizi yang normal. Namun, dalam penelitian ini pengukuran status gizi hanya berdasarkan pada IMT dan tidak dilakukan pengukuran zat gizi mikro esensial.

Faktor gizi yang dapat mempengaruhi gangguan penyerapan yodium adalah kekurangan energi protein atau defisiensi energi protein. Keadaan ini dapat memperberat masalah GAKI terutama di daerah gondok endemik. Konsumsi makanan sehari-hari anak dapat menggambarkan status gizinya, status gizi kurang atau buruk pada seseorang dapat berisiko pada terganggunya proses biosintesis hormon tiroid karena kurangnya TBP (Thyroxin Binding Protein), sehingga hormon tiroid akan kurang disintesis (Djokomoeljanto, 2007).

Protein menjadi zat gizi yang sangat berperan dalam biosintesis hormon tiroid, lebih baik.

sebagai contoh dalam tahapan hormonogenesis terdapat glikoprotein khusus yaitu Tiroglobulin (Tg) (Price \& Wilson, 2006). Protein kunci lain yang akan berperan adalah tiroperoksidase (TPO). TPO adalah glikoprotein yang melekat pada membran. Enzim ini menjembatani oksidasi ion iodida dan penempelan iodine pada residu tirosine di tiroglobulin. Kemudian dalam sistem transpor, hormon tiroid disalurkan dalam darah dalam bentuk terikat dengan carrier protein. Meski hanya $0,04 \%$ T4 dan 0,4\% T3 dalam bentuk bebas, bentuk inilah yang memiliki efek dalam tubuh. Terdapat 3 protein pembawa hormon tiroid, meliputi: TBG Thyroid Binding Globulin, TBPA Thyroid Binding Prealbumin disebut juga transthyretin dan albumin. Peran umum semua protein transpor tersebut yaitu untuk melindungi paparan yang terlalu besar di jaringan dan sebagai simpanan yang sewaktu-waktu dapat digunakan. Sejumlah 3-6\% T4 dan T3 terikat dengan lipoprotein (Djokomoeljanto, 2007).

Hal ini sejalan dengan penelitian yang pernah dilakukan oleh Patuti et al., (2010) menunjukkan bahwa rendahnya konsumsi sumber protein dapat 
JURNAL ILMU KESEHATAN BHAKTI HUSADA:

HEALTH SCIENCES JOURNAL, Vol. 11 No. 02, DESEMBER 2020 DOI: $10.34305 /$ jikbh.v11i2.168
Ciptaan disebarluaskan di bawah Lisensi Creative Commons AtribusiNonKomersial-BerbagiSerupa 4.0 menyebabkan seseorang berpeluang menderita GAKI sebesar 30,6 kali lebih besar dibandingkan dengan seseorang yang tidak menderita GAKI. Salah satu manifestasi klinis dari spektrum GAKI adalah kejadian gondok, dimana terjadi pembesaran kelenjar tiroid yang diakibatkan oleh disfungsi kelenjar tiroid yang bekerja lebih keras dalam memproduksi hormon tiroid (Djokomoeljanto, 2007).

\section{Konsumsi Zat Goitrogenik}

Faktor lainnya yang menjadi kecurigaan tidak adanya hubungan adalah indikasi adanya paparan zat goitrogenik pada makanan yang dikonsumsi. Goitrogen adalah bahan kimia yang bersifat toksik pada kelenjar tiroid (Kartono \& Moeljanto, 2009).

Zat goitrogenik dalam bahan makanan yang dimakan setiap hari dapat menyebabkan pembesaran kelenjar tiroid dan dapat mengganggu hormonogenesis sehingga dapat membesarkan kelenjar tiroid. Zat goitrogen dalam bahan makanan dapat dibagi menjadi kelompok tiosianat dan tiourea: Kelompok tiosianat atau senyawa mirip tiosianat yang secara primer menghambat mekanisme transport aktif iodium ke dalam kelenjar tiroid. Makananmakanan tinggi tiosianat adalah singkong, jagung, rebung, ubi jalar, kubis, selada air, daun melinjo dan buncis besar (Triyono, 2004). Kelompok tiourea, thionamide, tioglicoside, bioflavonoid dan disulfide alifatik. Kelompok ini bekerja menghambat organifikasi yodium dan penggabungan yodotirosin dalam pembentukan hormon tiroid aktif. Kelompok ini ditemukan dengan konsentrasi tinggi dalam bahan makanan seperti: sorgum, kacangkacangan, bawang merah dan garlic (Triyono, 2004).

Menurut Thaha et al., (2002) konsumsi makanan yang mengandung tiosianat lebih tinggi dengan rata-rata konsumsi bahan makanan yang mengandung zat goitrogenik tiga kali dalam sehari pada daerah endemik GAKI serta tiosianat merupakan faktor risiko penting terhadap endemisitas GAKI.

Penelitian yang dilakukan oleh Kusuma \& Budiono, (2016); Nurarif \& Kusuma, (2015) memperlihatkan bahwa dengan mengkonsumsi bahan makanan yang mengandung zat goitrogenik akan bermakna secara signifikan dengan kejadian GAKI pada anak-anak dengan usia sekolah. Chobanian et al., n.d. (2009) menyebutkan 
JURNAL ILMU KESEHATAN BHAKTI HUSADA:

HEALTH SCIENCES JOURNAL, Vol. 11 No. 02, DESEMBER 2020 DOI: $10.34305 /$ jikbh.v11i2.168
Ciptaan disebarluaskan di bawah Lisensi Creative Commons Atribusi-

NonKomersial-BerbagiSerupa 4.0 bahwa kondisi GAKI pada anak-anak dan remaja dapat menyebabkan kejadian gondok. Sejalan dengan penelitian tersebut, menurut Mezgebu et al., (2012) anak-anak usia sekolah (6-12 tahun) di wilayah Ethiopia yang sering mengkonsumsi sayuran kubis dimana merupakan salah satu sumber goitrogenik akan berisiko menderita gondok dibandingkan kelompok anak-anak yang tidak pernah mengkonsumsi kubis.

\section{Kandungan Air Minum}

Kondisi geografis dan lingkungan suatu wilayah akan mempengaruhi kadar iodium dalam tanah dan airnya. Secara geografis Kab Brebes merupakan daerah yang berbatasan langsung dengan laut jawa. Kabupaten Brebes memiliki lahan persawahan sebesar 62,703 hektar, sedangkan lahan persawahan di wilayah Kecamatan Bulakamba sebesar 7,411 hektar Rekapitulasi Hasil Palpasi GAKI Pada Anak Sekolah, Dinas Kesehatan Kabupaten Brebes 2014 (2014). Berbagai pencemaran dapat terjadi di wilayah pertanian dari mulai aktivitas penggunaan pestisida kimia dan pencemaran logam

\section{Kesimpulan}

berat yang berasal dari lautan (Saidin, 2009; SAMSUDIN \& Suryono, 2007).

Bahan goitrogenik non alamiah seperti pupuk urea dan pestisida, logam berat seperti timbal, merkuri dapat mengganggu proses produksi hormon tiroid. Proses masuknya zat-zat tersebut ke dalam sumber air minum masyarakat dapat dikaitkan dengan sumber air bersih yang digunakan. Zat-zat di atas merupakan kategori Endocrine Disrupting Chemicals (EDC) yang dapat berperan dalam peningkatan kejadian gondok termasuk diantaranya adalah pestisida dan logam berat. Asupan EDC pada tubuh manusia dapat menghambat pembentukan hormon tiroid karena akan membentuk ikatan yang lebih kuat dengan yodium (Klaassen \& Amdur, 2013).

Kadar EIU juga dapat berkaitan dengan adanya kontaminasi air minum dengan bakteri E.Coli dan coliform. Namun dalam penelitian ini tidak dilakukan pengukuran kandungan iodium dan kadar E. Coli dalam air minum masyarakat, sehingga tidak diketahui hubungannya dengan kejadian gondok yang terjadi.

Kadar Ekskresi Iodium Urine (EIU) anak-anak semuanya di atas kadar nilai kecukupannya $(120 \mu \mathrm{g} / \mathrm{dL})$; nilai minimum 
JURNAL ILMU KESEHATAN BHAKTI HUSADA:

HEALTH SCIENCES JOURNAL, Vol. 11 No. 02, DESEMBER 2020 DOI: $10.34305 /$ jikbh.v11i2.168

$152 \mu \mathrm{g} / \mathrm{dL}$ dan nilai maksimum $284 \mu \mathrm{g} / \mathrm{dL}$; mean $251,76 \mu \mathrm{g} / \mathrm{dL}$.

$$
\text { Sebanyak } 39,2 \% \text { responden }
$$
menderita gondok dengan tingkat keparahan meliputi grade 1 sebanyak 37,2\% dan grade 2 sebanyak $2 \%$.

Tidak terdapat hubungan yang signifikan antara Kadar Ekskresi Yodium Urine (EYU) dengan kejadian gondok $(\mathrm{p}=0,743)$.

\section{Daftar Pustaka}

Ah Yusuf, Rizky Fitryasari PK, \& Hanik Endang Nihayati. (2015). Buku Ajar Keperawatan Kesehatan Jiwa (Faqihani Ganiajri (Ed.)). Salemba Medika. http://www.ners.unair.ac.id/materikuli ah/buku ajar keperawatan kesehatan jiwa.pdf

Azizi, F. (2009). Iodine deficiency disorders: silent pandemic. Thyroid International, 4, 1-14.

Bürgi, H. (2010). Iodine excess. Best Practice \& Research Clinical Endocrinology \& Metabolism, 24(1), 107-115.

Chobanian, A. V, Bakris, G. L., Black, H. R., Cushman, W. C., Green, L. A., Izzo Jr, J. L., Jones, D. W., Materson, B. J., Oparil, S., \& Wright Jr, J. T. (n.d.). Almatsier S. 2009. Prinsip Dasar Ilmu Gizi. Jakarta: Gramedia Pustaka Utama. p 61. Anderson JW. 2004. Whole Grains and Coronary Heart Disease: The Whole Kernel of
Ciptaan disebarluaskan di bawah Lisensi Creative Commons AtribusiNonKomersial-BerbagiSerupa 4.0 Internasional.

Truth. Am J Clin Nutr, 6 (80): 14591460. Appel LJ. 1999.

Nonpharmacologic Therapies that Reduce Blood Pressure. Br J Nutr, 112(3), 457-466.

Djokomoeljanto, R. (2007). Buku ajar tiroidologi klinik. Semarang:

Universitas Diponegoro.

Dunn, J. T. (2002). The global challenge of iodine deficiency. Jurnal GAKY Indonesia, 1(1), 1-8.

Garber, J. R., Cobin, R. H., Gharib, H., Hennessey, J. V, Klein, I., Mechanick, J. I., Pessah-Pollack, R., Singer, P. A., $\&$ Woeber for the American Association of Clinical Endocrinologists and American Thyroid Association Taskforce on Hypothyroidism in Adults, K. A. (2012). Clinical practice guidelines for hypothyroidism in adults: cosponsored by the American Association of Clinical Endocrinologists and the American Thyroid Association. Thyroid, 22(12), 1200-1235.

Harjatmo, T. P., Rachmat, M., Pritasari, P., \& Hartono, A. S. (2017). Gambaran Kadar Iodium Dalam Garam Rumah Tangga Berdasarkan Kadar Iodium Dalam Garam Yang Dibeli Responden Di Kecamatan Warunggunung Kabupaten Lebak Banten. Media Gizi Mikro Indonesia, 9(1), 51-60.

Kartono, D. (1997). Prevalensi Gondok pada Anak Sekolah di Daerah Gondok Endemik di P. Jawa. Buletin Penelitian Kesehatan, 25(1).

Kartono, D., \& Moeljanto, D. (2009). Total goiter rate (tgr), ekskresi iodium urine 
JURNAL ILMU KESEHATAN BHAKTI HUSADA:

HEALTH SCIENCES JOURNAL, VOL. 11 NO. 02, DESEMBER 2020 DOI: $10.34305 /$ jikbh.v11i2.168

(eiu) dan konsumsi garam beriodium Di Propinsi Jawa Tengah. Buletin Penelitian Kesehatan, 36(2).

Klaassen, C. D., \& Amdur, M. O. (2013). Casarett and Doull's toxicology: the basic science of poisons (Vol. 1236). McGraw-Hill New York.

Kusuma, S. T., \& Budiono, I. (2016). Faktor Konsumsi yang berhubungan dengan Kejadian Gangguan Akibat Kekurangan Yodium pada Anak Sekolah Dasar (Studi Kasus di MI Depokharjo Parakan Kabupaten Temanggung). Unnes Journal of Public Health, 5(2), 149-155.

Mezgebu, Y., Mossie, A., Rajesh, P. N., \& Beyene, G. (2012). Prevalence and serverity of Iodine deficiency disorder among children 6-12 years of age in Shebe Senbo District, Jimma Zone, Southwest Ethiopia. Ethiopian Journal of Health Sciences, 22(3).

Nasional, B. P. P. (2004). Rencana Aksi Nasional Kesinambungan Program Penanggulangan GAKY. Jakarta: Badan Perencanaan Pembangunan Nasional, 4.

Nurarif, A. H., \& Kusuma, H. (2015). Aplikasi Asuhan Keperawatan Berdasarkan Diagnosa Medis dan Nanda Nic-Noc Edisi Revisi Jilid 2 (Revisi Jil). Mediaction Publishing.

Patuti, N., Sudargo, T., \& Wachid, D. N. (2010). Faktor-faktor yang berhubungan dengan kejadian GAKY pada anak sekolah dasar di pinggiran pantai Kota Palu Provinsi Sulawesi Tengah. Jurnal Gizi Klinik Indonesia, 7(1), 17-26.
Ciptaan disebarluaskan di bawah

Lisensi Creative Commons Atribusi-

NonKomersial-BerbagiSerupa 4.0 Internasional.

Price, S. A., \& Wilson, L. M. (2006). Patofisiologi konsep klinis prosesproses penyakit. Jakarta: Egc, 4(2), 1127-1128.

Rekapitulasi Hasil Palpasi GAKI Pada Anak Sekolah, Dinas Kesehatan Kabupaten Brebes 2014. (2014).

Saidin, S. (2009). Hubungan keadaan geografi dan lingkungan dengan gangguan akibat kurang yodium (GAKY). Media Penelitian Dan Pengembangan Kesehatan, 19(2).

SAMSUDIN, M., \& Suryono, B. (2007). Hubungan kadar Plumbum $(\mathrm{Pb})$ dalam darah dengan fungsi tiroid (TSH-FT4) di daerah perkotaan. [Yogyakarta]: Universitas Gadjah Mada.

Sebotsa, M. L. D., Dannhauser, A., Mollentze, W. F., Mollentze, G. M., Mahomed, F. A., \& Jooste, P. L. (2009). Knowledge, attitudes and practices regarding iodine among patients with hyperthyroidism in the Free State, South Africa. South African Journal of Clinical Nutrition, 22(1).

Sudarsono, A. I. (2001). Perbedaan Status Gaki Ibu Hamil Dan Tidak Hamil Di Kecamatan Buluspesantren Kabupaten Kebumen Propinsi Jawa Tengah. Program Pendidikan Pasca sarjana Universitas Diponegoro.

Susanto, R. (2009). KELAINAN TIROID MASA BAYI: Skrining Hipotiroidisme Neonatal, Hipotiroidisme Kongenital Dan Hipotiroidisme Didapat.

Syaifuddin, H. (2011). Anatomi Fisiologi: Kurikulum Berbasis Kompetensi Untuk Keperawatan \& Kebidanan. Jakarta: 
JURNAL ILMU KESEHATAN BHAKTI HUSADA:

HEALTH SCIENCES JOURNAL, VOL. 11 NO. 02, DESEMBER 2020 DOI: $10.34305 /$ jikbh.v11i2.168

EGC.

Thaha, A. R., Djunaidi, M., \& Nurhaedar, J. (2002). Analisis faktor risiko coastal goiter. Jurnal GAKY Indonesia, 1(1), 9-20.

Triyono, G. I. R. (2004). Identifikasi faktor yang diduga berhubungan dengan kejadian gondok pada anak sekolah dasar di daerah dataran rendah. Jurnal GAKY Indonesia, 3, 1-3.

Vanderpump, M. P. J. (2011). The
Ciptaan disebarluaskan di bawah Lisensi Creative Commons AtribusiNonKomersial-BerbagiSerupa 4.0 Internasional.

epidemiology of thyroid disease. British Medical Bulletin, 99(1).

Verma, M., \& Raghuvanshi, R. S. (2001). Dietary iodine intake and prevalence of iodine deficiency disorders in adults. Journal of Nutritional \& Environmental Medicine, 11(3), 175180.

Zimmermann, M. B. (2004). Assessing iodine status and monitoring progress of iodized salt programs. The Journal of Nutrition, 134(7), 1673-1677. 